\title{
Effect of Discussion and Invention Teaching Strategies on Secondary School Students on Retention of Chemistry Concepts in Delta State: Nigeria
}

\author{
Dr. E. A. Okurumeh \\ Reader, Mathematics and Science Education, College of Education; Warri, Delta state, Nigeria
}

\begin{abstract}
The study took step in finding the effect of discussion on retention of chemistry concepts. The moderating effects of academic ability and gender were also investigated. The study adopted a pre-test, post-test, follow up test, control group quasiexperimental design with a $3 \times 2 \times 2$ factorial matrix. The participants consisted of 224 senior secondary II chemistry students from intact classes in 9 selected secondary schools in Delta Central Senatorial District. The instrument for data collection include "chemistry retention test" $(r=0.84)$ "Ability test in chemistry" $(r=0.85)$ and Teachers instructional packages 3 research questions were raised and answered while 3 hypotheses were tested at 0.05 alpha levels. Data were analyzed using ANCOVA; while sheffe post-hoc analysis was used to explain the significant difference. There were significant effects of treatment on students retention of chemistry concepts (Fc2.803) $=151.94$ and student of varying abilities $\left.{ }_{(F c 11.242)}=2.03\right)$, but, there were no significant effect of treatment on gender of retention ability $($ Fc1.537) $=1.499)$ in chemistry. The discussion and invention instructional strategies improved students' retention of chemistry concepts more than the conventional lecture method. It was recommended that teachers should adopt the discussion and invention methods in teaching of chemistry at the secondary school.
\end{abstract}

Keywords: Discussion Strategy, Invention Strategy, Retention, Chemistry Concepts

\section{Background of the Problem}

The importance and uses of chemistry is a good reason for including it as a subject in the curriculum of senior secondary schools and tertiary schools all over the world. Its importance as a subject in the technological development of a nation has widely been reported. (Osokoya, 2002) Chemistry has contributed greatly to the development of mankind and provision of solutions to natural and artificial problems thus gaining prominence among other school subjects. On emphasis placed on the value of chemistry, the Joint Matriculation Board bronchure 2014 stated that a minimum credit pass in chemistry is required as one of the criteria for admitting candidate aspiring to do any science related course in the tertiary institutions. These include courses like medical and health sciences, physical sciences; engineering and a host of others. In spite of the recognition given to chemistry and its teaching; there has often been a gap between curriculum planners intention and classroom practice (Kempa and Aminah, 1991).

Effective teaching and learning of chemistry is dependent on the instructional strategy used. This is a major factor responsible for the poor level of achievement of students and their retention of chemistry concepts. Evidence from past research studies have shown that practicing chemistry teachers have relied so much on the traditional lecture teaching method of "talk and write" whereby the teacher gives some examples on the board and students copy the examples into exercise books and later gives problems to solve based on the examples given. This approach does not allow for students active participation in the learning process and has led to alternative teaching strategies which are more innovative promoting better learning of chemistry (Okurumeh, 2001, Adeoye; 2000, Alebiosu 1998, Ojo 1989).
The use of the traditional lecture method is often associated with poor performance in chemistry and poor enrolment in the subject as widely reported in the past studies within and outside Nigeria (Okurumeh 2012, Khan and Saeed; 2010, Orji 1998).

The traditional lecture instructional strategy involves the passing on of facts consisting of concepts through the teacher's one-way interaction of talking and giving notes. It has the following advantages as stated by Osokaja (2002);

It is concise II. It saves time III It gives stability to the curriculum.

However, the traditional lecture instructional strategy has been greatly criticized for been teacher-centred and not being capable of sustaining the interest of students throughout the instructional period/process (Oludipe and Awokoya 2010).

Studies done on instructional models whereby students participate in process of investigation and discussion with one another; with the teacher and learning materials have been shown to improve students fundamental understanding in science (Grouws and Cebulla 2000). Therefore, there is need for more alternative strategy that would be able to sustain the interest of student and that would involve a two way student-teacher; and student-student interactions. After a critical analysis of factors associated with the retention of facts in school chemistry; Esan (1999) suggested that investigation be conducted to determine the appropriate instructional methods best suited for the promotion of cognitive achievements and retention. The quest to determine the appropriate instructional strategies which will enhance retention of concepts by learners has produced a 


\section{International Journal of Science and Research (IJSR) \\ ISSN (Online): 2319-7064 \\ Index Copernicus Value (2013): 6.14 | Impact Factor (2014): 5.611}

variety of heuristic models and corresponding techniques. Ability to retain old learning while one continues to acquire new ones is a measure of good learning. Retention is the amount of materials remembered over-times; it involves recognition and recall. Recognition involves a process of comparison of information with memory. Recall involves search of memory and then the comparison process once something is found.

Discussion and Invention teaching strategies are cognitive techniques based on the constructive approach to science teaching. Also based on the belief that learning occurs as learners are actively involved in a process of meaning and knowledge construction of ideas as opposed to passively receiving information as in the traditional lecture method. Constructivist learning strategies include more reflective oriented learning activities such as exploratory learning which includes problem solving, group learning invention, discussion and situation learning (Murphy; 1997; Cobb and Yackel; 1991). Usingdiscussion as teaching strategy which according to Geoffrey (2001) carries a hidden message - the teacher is in effect saying to his or her student "I value your experience and I am interested in your opinion." This is in contrast to the unspoken words of students in a lecture in "talk and write" teaching strategy which is that the students knows nothing of value about the topic. Discussion could involve whole class or group working collaboratively together.

The benefits of discussion are:

- The promotion of learning of academic skills

- The enhancement of group relations

- The promotion of metacognition in which students achieve higher levels of thinking at quicker rate than if they worked independently.

- The improvement of academic achievement through greater concentration as they remember what have been discovered and said by themselves as well as what others have said.

Butan invention lesson gravitates around the following points:

- Introducing a lesson involving a new skill by possing it as a problem to be investigated,

- Help students understand concepts by providing the necessary environment and aids learning experiences and activities that students engaged in. these were provided by both the teachers and students.

- Stimulates students interest by moving round and asking questions on their activities and answering questions.

These are a number of factors within the learners that influence their ability to learn. Perhaps best known of these are cognitive factors such as intelligence and creativity; but there are other factors that can be of equal relevance to the teacher. These factors include affective, maturational, the learner's age, sex and social background, study habits and above all memory. But of consideration to the researcher are learners' ability and gender to chemistry education. The effect of gender on science and mathematics achievement has been a major debate among educators and researchers. For instance, some such as (Oyedeji 1996, Awofale 2000) have significant gender group difference in favour of male in mathematics and science. This study is focused in gender differences on retention of chemistry concepts in Nigerian Educational setting where mathematics and some science subjects such as physics and chemistry are given male image (Okpala and Onocha 1998). The paucity of girls and women in science and worse still in teaching technology is well documented in other studies (Allele-Williams; 1986, Balogun, 1994, Yoloye, 1980). However, Inyang and Jegede (1991), Iroegbu 1998, Okurumeh 2009) reported that gender had no effect on students achievement in science and mathematics. All these researches show that different views abound on the issue of gender in chemistry achievement and retention. This study is therefore interested in the effects of discussion strategy, ability levels and gender on senior secondary schools students' retention of chemistry concepts.

\section{Statement of the Problem}

The problem of the study is to determine the effect of discussion and invention strategies on student's retention of chemistry concepts and which of these - gender and abilities of students could enhance learning in chemistry using these strategies.

\section{Research Questions/Hypotheses}

This study tried to answer the following questions and the null hypotheses tested at 0.05 level of significance.

1) Will there be any effect of discussion and invention strategies on students' retention of chemistry concepts?

2) Will there be any effect of male and female students in the use of discussion and invention strategies on retention of chemistry concepts?

3) Will there be any effect on retention of students of varying abilities using discussion and invention strategies?

$\mathrm{H}_{0}$ 1: There is no significant effect in the retention of chemistry concepts among students exposed to discussion and invention and traditional lecture strategies.

$\mathrm{H}_{0}$ 2: There is no significant effect on retention of students of varying abilities using discussion and invention teaching strategies.

$\mathrm{H}_{0}$ 3: There is no significant effect in chemistry retention between male and female students exposed to two instructional strategies (Discussion and invention methods.)

\section{Significance of the Study}

The findings of the study will enable school administrators and teachers to get a good background of how teaching and learning should be and the level of retention of the students. The findings will give curriculum designers concrete ideas on areas for improvement such as curriculum development, comprehensibility of texts and simplified instructions. Also, it will provide useful information for future research work in the areas of organic and inorganic chemistry at the senior secondary school level.

\section{Scope and Delimitation of the Study}

The study involved nine public senior secondary schools in Delta Central Senatorial District of Delta State, Nigeria. The main concept taught was based on organic carbon compound in the scheme of work of the senior secondary syllabus. The 


\section{International Journal of Science and Research (IJSR) \\ ISSN (Online): 2319-7064 \\ Index Copernicus Value (2013): 6.14 | Impact Factor (2014): 5.611}

study involved 224 senior secondary II chemistry students and their teachers for eight weeks.

\section{Research Design}

The study adopted a pre-test, post-test, follow-up test and control group quasi-experimental design. To analyze the research data, 3 × 2 × 2 factorial matrix was employed.

\section{Instruments}

The study made use of the following instrument to gather data and information.

- Instructional unit

- Chemistry Retention Test (CRT)

- Ability Test in Chemistry (ATC)

- Teacher's instructional package.

\section{Validation of Instruments}

The chemistry retention test (CRT) and the Ability Test (ATC) were validly tested and their reliability coefficients estimate were obtained as follows CRT 0.84 and ABT 0.85 using Kuder-Richadson KR 20 formula.

\section{Data analysis}

The data obtained from the study were analyzed using inferential statistics of analysis of covariance (ANCOVA) and variance. This was done to determine the group difference using pre-test scores as covariate. Multiple classification analysis (MCA) was used to find out whether the actual source of the significant difference if any, SheffePost Hoc Test was performed on the mean scores of the group.

\section{Results and Discussion}

$\mathrm{Ho}_{1}$ : There is no significant effect in the retention of chemistry concepts among students exposed to discussion and invention and conventional traditional lecture strategies. The following tables $1,2,3$, and 4 are the results of analysis of hypothesis 1 and questions 1,2 and 3 .

Table 1: ANOVA

Retention

\begin{tabular}{|c|c|c|c|c|c|}
\hline & $\begin{array}{c}\text { Sum of the } \\
\text { squares }\end{array}$ & Df & $\begin{array}{c}\text { Mean } \\
\text { square }\end{array}$ & F & Sig. \\
\hline Between groups & 426.269 & 2 & 213.135 & 55.424 & .000 \\
\hline Within groups & 849.856 & 221 & 3.846 & & \\
\hline Total & 1271.125 & 223 & & & \\
\hline
\end{tabular}

From the analysis, treatment has significant effect on student retention of chemistry concepts $\left.{ }_{(\mathrm{Fc} 2.803)}=\mathrm{P}<.05\right)$. This shows that students exposed to discussion and conventional traditional lecture strategies differ significantly on their follow-up test scores. Hence hypothesis 1 is rejected.

To buttress the result, Table 1 one way ANOVA of retention (gain) ${ }_{(\mathrm{Fc} 2.803)}=55.424 ; \mathrm{P}<0.05$ ) was significant, which further rejects the hypothesis 2 .

Further, the actual source of the significant difference of retention was traced using Post-hoc analysis. Results are summarized in Table 2.

Table 2

Sheffe Post Hoc test - Multiple Comparisons Dependent Variable: Retention

\begin{tabular}{|c|c|c|}
\hline (i) Treatment Groups (J) treatment Group & 95\% confidence & 95\% confidence \\
\cline { 3 - 3 } & & Upper bound \\
\hline Control experiment gp1 experimental gp2 & 1.95 & 3.56 \\
& 2.32 & 3.89 \\
\hline Experimental gp1 Control & -3.56 & -1.94 \\
experimental gp2 & -43 & 1.14 \\
\hline Experimental gp2 Control & -3.89 & -2.32 \\
experimental GP2 & -1.14 & 0.43 \\
\hline
\end{tabular}

Table 2 shows that each of the six possible pairs of treatment groups in the study produced significant differences except for experiment gp1 and experiment gp2. This goes to show that all the four other pairs contributed to the significance of treatment effect on retention.
Hypothesis 2: There is no significant effect in chemistry retention between male and female students exposed to two instructional strategies.

Table 3:

Summary of ANCOVA of retention of male and female students

Test of between subject effects

Dependable variable: Retention

\begin{tabular}{|c|c|c|c|c|c|}
\hline Source & Type III sum of square & Df & Mean square & $\mathrm{F}$ & Sig. \\
\hline $\begin{array}{l}\text { Intercept Hypothesis } \\
\text { Error }\end{array}$ & $\begin{array}{c}576.046 \\
72.765\end{array}$ & $\begin{array}{c}1 \\
2.575\end{array}$ & $\begin{array}{c}576.046 \\
28.255(\mathrm{a})\end{array}$ & 20.387 & .028 \\
\hline $\begin{array}{l}\text { Ability Hypothesis } \\
\text { Error }\end{array}$ & $\begin{array}{c}3.972 \\
830.940\end{array}$ & $\begin{array}{c}1 \\
217\end{array}$ & $\begin{array}{c}3.972 \\
3.829(\mathrm{~b})\end{array}$ & 1.037 & .310 \\
\hline $\begin{array}{l}\text { Gender* Hypothesis } \\
\text { Error }\end{array}$ & $\begin{array}{c}4.495 \\
10.816\end{array}$ & $\begin{array}{c}1 \\
2.001\end{array}$ & $\begin{array}{c}4.495 \\
5.407(\mathrm{c})\end{array}$ & 0.831 & .458 \\
\hline $\begin{array}{l}\text { Trtgp. Hypothesis } \\
\text { Error }\end{array}$ & $\begin{array}{c}403.880 \\
10.880\end{array}$ & $\begin{array}{c}2 \\
2.015\end{array}$ & $\begin{array}{l}201.940 \\
5.399(d)\end{array}$ & 37.405 & .026 \\
\hline Gender* Hypothesis & 10.814 & 2 & 5.407 & 1.412 & .026 \\
\hline TrtgpError & 830.940 & 217 & 3.829 & & \\
\hline
\end{tabular}




\section{International Journal of Science and Research (IJSR) \\ ISSN (Online): 2319-7064}

Index Copernicus Value (2013): 6.14 | Impact Factor (2014): 5.611

a. . 123Ms (trt group) $+.877 \mathrm{Ms}$ (Error)

b. Ms (Error)

c. $1.000 \mathrm{Ms}$

d. $.995 \mathrm{Ms}($ Gender * trt group) $+.005 \mathrm{Ms}$ (Error)

Table 4: Analysis of one way ANOVA of Retention between groups and within groups Retention

\begin{tabular}{|c|c|c|c|c|c|}
\hline & Sum of square & Df & Mean square & F & Sig. \\
\hline Between groups & 5.373 & 1 & 5.373 & .939 & .334 \\
\hline Within groups & 1270.752 & 222 & 5.724 & & \\
\hline Total & 1276.125 & 223 & & & \\
\hline
\end{tabular}

Table 4 shows that there is no significant effect in chemistry retention between male and female students exposed to discussion and invention and traditional lecture methods.

Instructional strategy $\left._{(\mathrm{Fc} 2.005)}=1.412 \mathrm{P}<0.05\right)$. The gain scores was used to compute the one way ANOVA Table 5. $(\mathrm{Fc} 1.00)=0.939, \mathrm{P}<.05)$ is not significant. Hence hypothesis 2 is accepted.

$\mathrm{HO}_{3}$ : There is no significant effect among student of varying abilities using discussion and invention and Traditional lecture strategies.

Table 6:Test of Between-Subjects Effects Summary of ANCOVA of ability on student retention in chemistry

\begin{tabular}{|c|c|c|c|c|c|}
\hline Source: Dependent variable & Type III Sum of square & DF & Mean square & F & Sig. \\
\hline Corrected Model:Ab Post & $283.531 \mathrm{a}$ & 12 & 23.638 & 6.920 & .000 \\
Ab Follow up test & 444.1316 & 12 & 37.011 & 7.253 & .000 \\
\hline Intercept:Ab Post & 11266.459 & 1 & 11266.459 & 3299.683 & .000 \\
Ab Follow up & 9253.161 & 1 & 9253.161 & 1813.320 & .000 \\
\hline Ab Pre-test:Ab Post & 181.267 & 1 & 181.267 & 53.088 & .000 \\
Ab Follow up test & 231.130 & 1 & 231.130 & 45.294 & .000 \\
\hline Retention:Ab Post & 76.093 & 11 & 6.918 & 2.026 & .027 \\
Ab Follow up test & 167.037 & 11 & 15.185 & 2.976 & .001 \\
\hline Error:Ab Post & 720.451 & 211 & 3.414 & & \\
Ab Follow up test & 1076.708 & 211 & 5.103 & & \\
\hline Total: Ab Post & 54882.000 & 224 & & & \\
Ab Follow up test & 44036.00 & 224 & & & \\
\hline Corrected Total:Ab Post & 1003.982 & 223 & & & \\
Ab Follow up test & 1520.839 & 223 & & & \\
\hline
\end{tabular}

a. $\mathrm{R}$ Squared $=.282$ (Adjusted R Squared $=0242)$

b. R Squared $=292$ (Adjusted R Squared $=252$ )

Table 5 shows that there is significant difference in retention among students of varying abilities taught with discussion and invention and traditional lecture methods both in Post-test and Follow-up (Fc11.242) $=2.026$; $\mathrm{P}<.05$ ) and Fc11.252 $=2.976$. Therefore,the hypothesis is rejected.

Table 6: Summary of ANCOVA of student's ability on retention in chemistry

Test of between-subjects effects

Dependable variable-retention

\begin{tabular}{|c|c|c|c|c|c|}
\hline Source & $\begin{array}{c}\text { Type III } \\
\text { Sum of } \\
\text { squares }\end{array}$ & DF & $\begin{array}{c}\text { Mean } \\
\text { Square }\end{array}$ & F & Sig. \\
\hline $\begin{array}{c}\text { Corrected } \\
\text { Model }\end{array}$ & $429.199 \mathrm{a}$ & 3 & 143.066 & 37.163 & .000 \\
\hline Intercept & 565.047 & 1 & 565.047 & 146.778 & .000 \\
\hline Ability & 2.929 & 1 & 2.929 & .761 & .384 \\
\hline Trt group & 413.047 & 2 & 206.524 & 53.647 & $.000^{*}$ \\
\hline Error & 5204.000 & 220 & 3.850 & & \\
\hline Total & 5204.000 & 224 & & & \\
\hline Corrected total & 1276.125 & 223 & & & \\
\hline
\end{tabular}

Table 5 shows that there is significant difference in retention among students of varying abilities taught with discussion and invention and traditional lecture methods both in Posttest and Follow-up test $\left.{ }_{(\mathrm{Fc} 11.242)}=2.026 ; \mathrm{P}<.05\right)$ and ${ }_{\mathrm{Fc} 11.252}$ 2.976. Therefore the hypothesis is rejected.

Table 6, equally shows that there is significant difference in ability of student's retention in chemistry.

$\left.{ }_{(\mathrm{Fc} 2.327)}=53.647, \mathrm{P}<.05\right)$ is significant. The hypothesis is completely rejected.

\section{Discussion of Result}

The findings of the study in tables $1,2,3,4,5$, and 6 revealed that there are significant effects in the two strategies used. An interesting aspect in the retention is the fact that discussion strategy surpassed the conventional lecture method.So also the invention strategy surpassed both the discussion and conventional lecture methods. There is an improvement of academic achievement through greater concentration as they remember what have been learnt and said by themselves as well as what others have said.Though when compared. The retention using discussion and invention show no significant effect from one another. This finding agrees with the study of Zemelman and Hyde (1993) which asserts that learning in all subject areas involves constructing new ideas. However, the findings of Onyejiaku (1982), Unuero 2006 found no significant effect in teaching methods in terms of retention in science and mathematics and that no research finding is conclusive on what method to use in teaching the students.

The finding also indicated that there is no significant mean effect of students' gender on retention of chemistry concepts. The performance of males was not significantly different from that of the females in this study. Though a number of studies have been carried out in the past on the effect of gender on performance in physical sciences, many of which revealed that males tend to perform better than 


\section{International Journal of Science and Research (IJSR) \\ ISSN (Online): 2319-7064 \\ Index Copernicus Value (2013): 6.14 | Impact Factor (2014): 5.611}

females.Okpala and Onocha (1998), Unuero (2006) have found significant gender group difference in favour of males. This study, however; agreed with studies such as that of Oyedeji (1992) and Iroegbu (1998), Okurumeh (2009) which did not establish such difference.

The result of the study also revealed that there is a significant effect of ability level on students retention in chemistry. What this means is that students with high academic ability level performed best and followed by medium ability level and the low ability level least. This result is in line with Olowojaiye (2004) where she found significant effect of ability on students' cognitive achievement in mathematics.

\section{Summary and Conclusion}

1) There were significant effects of treatment on students' retention of chemistry concepts. Students in the treatment group obtained higher Post-test mean scores and higher follow-up test mean scores thanthose in the control group.

2) There were no significant interaction effects of treatment and gender on senior secondary students' retention in chemistry concepts.

3) There were no significant effects of treatment on ability of senior secondary students in Retention of chemistry concepts.

Based on the findings of this study, the following conclusions are drawn:

- The discussion and invention Strategies are very effective in promoting and increasing students' Retention in chemistry concepts than the conventional lecture method.

- Discussion and invention strategies could bridge the gap in terms of performance between the low, medium and high abilities groups.

- It was also found that the Conventional (traditional) teaching method amplified gender disparity in retention of chemistry concepts.

This study will redefine the role of chemistry teachers on the choice and use of instructional strategies to improve, promote achievement, ability and retention in chemistry in the senior secondary schools.

\section{References}

[1] Adegbile; A (2002); Advance Organizer and the Secondary Schools Teachers, in Ayodele; S. O. (ed). Teaching strategies for Nigeria Secondary Schools.Powerhouse Press Ibadan; Nigeria.

[2] Adeoye, F. A.(2002) Assessment Procedure, Cognitive Style and gender as determinants of students' performance in hierarchical cognitive tasks in physics. Unpublished Ph.D Thesis, University of Ibadan; Ibadan.

[3] Adepoju, T. L. (2001) Location factors as correlates of private and academic performance of secondary schools in Oyo State. A proposal presented at the Higher Students Joint Staff Seminar; Department of Teacher Education, University of Ibadan; Ibadan.
[4] Adepeju, T. L. (1999) Principles and practice of Primary Education, Nigeria; Ibadan Corporate Publications.

[5] Adesoji; F. A. (2002); Modern Strategies in the teaching of Integrated Science in AyodeleS. O. (Ed) Teaching strategies for Nigerian Secondary Schools, pg. $205-212$.

[6] Ajaja; O. P. and Kpangban E. (2002); Enriching Biology Teaching in the $21^{\text {st }}$ Century in Nigeria. Implications for Teachers.Journal of the Science Teachers Association of Nigeria 32(2) 38 - 39.

[7] Alebiosu; K. A. (1998); Effects of two cooperative learning outcomes in Chemistry. Unpublished Ph.D Thesis University of Ibadan, Ibadan.

[8] Alele-Williams, G (1986); Education for Women for national development.A keynote address at a workshop on women's education in Nigeria; Federal Ministry of Education; Lagos.

[9] Aremu; A (1999); Strategies for improving the performance of female pupils in Mathematics.African Journal of Education Research 5(1) 77-85.

[10] Awofala; A. O. A; (2000); The status of Mathematics teaching and learning in primary school at the tear 2000: (Unpublished B.ed Project; University of Ibadan; Nigeria.

[11] Balogun T. A. (1994); Gender issues in the teaching of STM in Erinoslo S. Y. (Ed);

[12] Perspective on women in science and technology in Nigeria; Ibadan; San Bookman Educational and Communications Services.

[13] Cobb, P. Yackeh, E. and Wood; T (1993). A constructivism alternative to Representational view of mind in Mathematics education.Journal for research in Mathematics education 23; 2 - 23.

[14] Esan A. O. (1999); Effects of cooperative and individualistic problem-solving strategies on students learning outcomes in secondary school mathematics; Unpublished Ph.D Thesis; University of Ibadan; Ibadan.

[15] Geoffrey, P (2001); Teaching Today.A practical guide.( $2^{\text {nd }}$ Ed.) Nelson Thornes Ltd; Delta Place 27, bath Road Cheltenham: G 1537 the United Kingdom.

[16] Grown; D. A. and Cebulla; K. J (2000) Improving students achievement in Mathematics; Geneva Switzerland; International Academy of Education.University; Columbus; Ohio.

[17] Hutchinson; J. S (2000); Case studies in chemistry; Interactive and inductive learning. Department of Chemistry; Rice University Houston. U.S.A retrieved from http://jshutch@rice.edu

[18] Igwe, I. O (2001); Relative Effects of Framing and Team assisted Instructional Strategies on students learning outcomes in selected difficult chemistry concepts. Unpublished Ph.D proposal, University of Ibadan; Nigeria

[19] Iroegbu; T. O (1998). Problem based learning: Numerical ability and Genders as Determinants of Achievement in line graphing. An unpublished Ph.D Thesis; University of Ibadan; Ibadan

[20] Kempa, R andAminah, A (1991); Interactions in group work in science; International Journal of Science Education; 13 93) pp 341 - 354 


\section{International Journal of Science and Research (IJSR) \\ ISSN (Online): 2319-7064 \\ Index Copernicus Value (2013): 6.14 | Impact Factor (2014): 5.611}

[21] Kpeke; E. E and Osho, I (1997). Approaches; Methods; Strategies and Techniques of teaching in Inomiesa; E. A. and Osakwe; E. O. (Ed). Principles and practice of teaching for students in tertiary institutions.Pp 32-50 Abort Research Publishers;

[22] Okpala; M. P. and Onocha (1988); Students factors as correlation of achievement in Physics Education.A Journal of Physics Institute; 23(53)

[23] Olowojaiye; F. B (2004); Effects of behavioural objective based and study question based instructional strategies on students learning outcomes in Senior Secondary mathematics in Lagos State. An unpublished Ph.D Thesis; University of Ibadan; Nigeria

[24] Onyejiake; F.O (1982) cognitive instructional strategies and performance"the journal of experimental education 51(ii) parking,H.J (1968) innovation in higher education. new universities in united kingdom pg 173

[25] Ojo,M.O(1989); the differential effectives act cooperative competitive and in individuals goal structure on students performance in chemistry. Unpublished Ph.dthesis;Universityof Ibadan,Nigeria.

[26] Ochonogor; E. C andAjaja;o.p(2005); teaching methods- a multi-disciplinary.obielium Nigeria enterprise,p; oshinderostreet;odo- eran;Itre; surulere;lagosnigeria

[27] Oludipe; D andAwokoyaJ.O(2010); effects of cooperatives learning teaching strategy on the reduction of students anxiety for learning chemistry journal of Turkish science education

[28] Orji; A. B. C.(1998). Effects of problem solving and concepts mapping instructional strategies on student's learning outcome in physics. Unpublished phdthesis,university of Ibadan,Nigeria.

[29] Osokoya; M. M(2002); modern thrends in the teaching of secondary schools chemistry. In ayodele;S.O(ED) teaching strategies for Nigeria secondary school.

[30] Oyedeji; O.A(1996) Assessing gender factors in some science and mathematics test in Nigeria;Zimbabwe journal of education.

[31] Okurumeh E. A.(2004); Effects of meaning focus invention and discussion strategies on senior secondary students in mathematics. Global Journal of mathematics and statistics. Global publication, 1 Ramaprasal Roy lane,Calculta 700006,India in collaboration with institute of Science and Technology,India.

[32] Okurumeh E(2012), Effects of discussion and invention teaching strategies on senior secondary school student's achievements in chemistry in delta state; M.Ed thesis Delta state university; Abraka. Unpublished.

[33] Shaw; E. L and Doan; R.L(1990). Investigation of the differences in attitude and achievement between male and female of second and fifth grade science student. Paper presented at annual meeting of the national association for research in science teaching.

[34] Ughamadu; K.A(1998). Educational Technology concepts; principles and application. Kmensuo educational publishers Onitsha/Agbor.

[35] Unuero; J. U(2006). Comparative study of guided discovery; lecture and concepts mapping methods of teaching geometry in secondary schools. Unpublished Ph.d thesis.Delta state university, Abraka, Nigeria.

[36] Vygotsky; L. S(1978). Mind in Society; The development of higher mental processes. Cambridge M.A Havard University Press.

[37] Zemelman; S. D.andHyde;A(1993). Best practice: New standard for teaching and learning in American schools. Portsmouth;

[38] Yoloye; E. A. (1980). Developing and understanding of education; Ibadan University Publishing Home. 